\title{
Understanding the long-term policy influence strategies of the tobacco industry: two contemporary case studies
}

\author{
Thomas R Hird (D) , 1 Allen William Andrew Gallagher (D) ,' Karen Evans-Reeves, \\ Mateusz Zatoński, ${ }_{1}^{1}$ Sarah Dance, ${ }^{1}$ Pascal A Diethelm, ${ }^{2}$ Richard Edwards (D) , \\ Anna B Gilmore (D) ${ }^{1}$
}

\begin{abstract}
- Additional supplemental material is published online only. To view, please visit the journal online (http://dx.doi. org/10.1136/tobaccocontrol2021-057030).
\end{abstract}

'Department for Health, University of Bath, Bath, UK

${ }^{2}$ OxySuisse, Geneva, Switzerland ${ }^{3}$ Department of Public Health, University of Otago, Wellington, New Zealand

\section{Correspondence to}

Dr Thomas R Hird, Department for Health, University of Bath, Bath BA2 7AY, UK; trh45@bath.ac.uk

Received 2 September 2021 Accepted 22 December 2021
Check for updates

(C) Author(s) (or their employer(s)) 2022. No commercial re-use. See rights and permissions. Published by BMJ.

To cite: Hird TR

Gallagher AWA, Evans-

Reeves $\mathrm{K}$, et al. Tob Control 2022:31:297-307.

\begin{abstract}
Objective This paper explores transnational tobacco companies' (TTCS) long-term policy influence strategies using two case studies, harm reduction and illicit tobacco, to identify lessons for the tobacco control movement and wider efforts to address the commercial determinants of health.

Methods Evidence from a broad combination of sources including leaked documents and findings from over two decades of TTC monitoring were reviewed for each case study and categorised using the Policy Dystopia Model, focusing on the primary discursive strategy and key instrumental (action-based) strategies used.
\end{abstract}

Results In both case studies, TTCs seek to advance their interests by engaging primarily in reputation management, coalition management and information management strategies over the long-term to propagate their over-riding discursive strategy - 'we've changed, we are part of the solution' - despite clear evidence from both case studies that this is not the case. These strategies are globally coordinated and attempt primarily to reshape norms towards TTC involvement in tobacco control policy and delivery. Findings also suggest that industry denormalisation and the advent of Article 5.3 have led to the TTCs growing use of increasingly complex and opaque 'webs of influence'.

Conclusions The tobacco control community must develop its own proactive long-term strategies which should include industry denormalisation, new ways to fund research that reduce industry control, and improved transparency measures for research and policy. These findings, including TTC adaptations to Article 5.3, also indicate the need for more structural solutions, addressing corporate power and the underlying political and economic system. These lessons can be applied to other unhealthy commodity industries.

\section{INTRODUCTION}

Thirty years of research and analysis in Tobacco Control provide the opportunity to step back and critically appraise the advances made in understanding and addressing the tobacco industry as the primary vector of the global tobacco epidemic. ${ }^{12}$ This is particularly timely given that, responding to the success of tobacco control activities, transnational tobacco companies (TTCs) are redoubling their aggression and remain a crucial barrier to further progress (box 1). ${ }^{3-6}$ Perhaps as a result, declines in smoking prevalence appear to be stalling and most countries have not had sufficient decreases to offset population growth, ${ }^{7}$ resulting in all-time high of 1.1 billion smokers in 2019, over three-quarters of whom live in low-income and middle-income countries. ${ }^{57}$

Great advances have been made in understanding the TTCs' short-term reactive corporate political activity to prevent, delay or divert tobacco control policies, ${ }^{8}$ with the accumulation of thousands of case studies enabling a sophisticated understanding of these tactics. ${ }^{9-11}$ These insights have been operationalised to good effect in protecting and advancing diverse policies across multiple jurisdictional levels. ${ }^{9} 101213$ There has, however, been comparatively little work on the proactive long-term policy influence strategies, despite leaked documents showing TTCs plan for the long term. ${ }^{14-16}$ There is, therefore, an urgent need address this gap.

This paper aims to explore the TTCs' long-term influence strategies using two case studies: harm reduction and the illicit tobacco trade, two key policy areas in which TTCs have a long history of engagement and have in recent years redoubled their influence efforts. In this way, we aim to identify lessons for the tobacco control movement and the commercial determinants of health more broadly.

\section{METHODS}

We selected harm reduction and illicit tobacco as our two case studies. We drew on multiple sources of evidence including previous research, recently leaked TTC documents and material obtained through established routine monitoring of TTC activities. The latter involves established Google alerts on all TTCs and on key areas of their activity and brands, regular searches of tobacco industry and retail journals and information provided from a wide network of informants.

We analysed these sources to identify industry strategies which we categorised using the Policy Dystopia Model (PDM) as our conceptual framework. The PDM is an evidence-based taxonomy of tobacco industry political activity derived from systematic reviews of industry influence on policy. ${ }^{10}$ The PDM has been shown to capture key elements of TTC influence strategies in a range of settings, dividing these into discursive (argument-based) and instrumental (action-based) strategies (see online supplemental tables 1 and 2). While the PDM 
Box 1 Background: the existential threat driving TTCs strategies

TTCs' business models involve manufacturing tobacco products at a very low cost and maintaining their sale at relatively high prices, resulting in massive profit margins. In 2020, PMI's profit margin was $40.8 \%$, BAT's was $38.6 \%$, JTI's was $22.4 \%$ and Imperial Brands' was $41.2 \%$, with combined profits of just under US $\$ 33 \mathrm{bn} .^{50} 109$ These margins enable both huge reinvestment, for example, in marketing or lobbying budgets, and the promise of ever increasing shareholder dividends. However, as a result of advances in tobacco control, cigarette sales have been falling since $2013 .{ }^{56}$ TTCs were initially able to maintain and even increase profits by exploiting their market power and overshifting taxes such that their price increases more than offset the decline in cigarette sales volumes. ${ }^{6}$ However, more recently, continued tax increases and implementation of tobacco control measures appear to have precipitated a tipping point where declining sales are no longer offset by overshifting, and profitability is falling. ${ }^{16110} 111$

This fundamental, existential threat for TTCs has driven: aggressive responses to prevent rises in tobacco taxes around the world; involvement in tobacco smuggling as a means of tax avoidance (discussed in Case Study 2); undermining the impact of tax increases on consumption and prevalence ${ }^{111112}$ and heavy investment in 'product innovation' in HTPs and e-cigarettes. This investment arguably provides the best opportunity to replicate the oligopoly control they benefit from in the cigarette market and, if they remain untaxed or taxed at low level, provides a new route to profits while also allowing them to attempt a hostile takeover of the harm reduction narrative (discussed in Case Study 1). ${ }^{1617113}$

BAT, British American Tobacco; HTP, heated tobacco product; JTI, Japan Tobacco International; PMI, Philip Morris International; TTC, transnational tobacco companies.

defines illicit trade as an instrumental strategy, here we focus on the TTC's narrative around illicit trade. ${ }^{1-19}$ We sought to identify the primary discursive and key instrumental strategies that best captured the long-term influence strategies in both case studies. Triangulation, prolonged engagement, persistent observation and discussion among authors were used to test the validity of our findings. ${ }^{20} 21$

\section{Case study 1: TTCs use of harm reduction as a long-term 'pathway to profit' strategy (1950s-2021)}

Since the 1950s when the links between smoking and lung cancer became known, ${ }^{22}$ TTCs have attempted to ward off the denormalisation of the industry and threats to their cigarette sales by professing a commitment to harm reduction, and actions such as introducing cigarette filters (1950s), 'light' cigarettes (1970s) and investing in smokeless tobacco options such as snus and nicotine pouches (2000s). These actions were supported by broader communication strategies and activities (table 1). ${ }^{23-27}$ Now, TTCs have once again returned to harm reduction. Seen with the context of previous actions, this is most likely the latest manifestation of the long-term strategy of seeking to rebuild credibility to secure policy influence and boost declining sales and profits. ${ }^{28}$

While recognising that other TTCs have developed similar 'transformational' narratives, ${ }^{29-32}$ in this case study we focus on Philip Morris International (PMI). ${ }^{28}$ PMI has led the latest iteration of this historic tactic and recently leaked documents give a unique insight into its long term strategies around harm reduction. ${ }^{1628}$ Our analysis identified PMI's utilisation of three main and inter-linked instrumental strategies-reputation management, information management and coalition management-to convince the world of its commitment to harm reduction both historically (table 1) and currently. Below, we consider each in turn.

\section{Reputation management}

In 2018, PMI announced it was 'giving up cigarettes' as part of a slew of transformation rhetoric around its supposed reincarnation into a disruptive technology company. ${ }^{33}$ PMI pledged to 'unsmoke' the world by promoting a 'switch' to its heated tobacco product, iqos, ${ }^{34} 35$ despite simultaneously claiming that heated tobacco products (HTPs) are not intended to help quitting, ${ }^{36}$ and a lack of independent evidence that they reduce health harms compared with cigarettes. ${ }^{37}$ Furthermore, the true motivation appears to be maximise sales and profits rather than to improve population health. Evidence for this includes the high price (and even greater profitability relative to cigarettes) of iqosand PMI's targeting of iqosmostly at high-income countries with relatively strong tobacco control policies (ie, where smoking was already declining) while continuing to invest in and market cigarettes elsewhere. ${ }^{1638}$

Leaked documents from 2014 reveal PMI's long-term strategy to appropriate harm reduction to renormalise its image as a 'trusted and indispensable partner, leading its sector and bringing solutions to the table. ${ }^{28}{ }^{39}$ Using the guise of transformation, PMI has harnessed the media and piggybacked on global platforms such as the World Economic Forum, G20 summit and UN General Assembly, to give the impression that it is a trusted partner of the global political and public health communities. ${ }^{1640-43}$ At a national level, PMI is attempting to operationalise its newly constructed reputation as a public health partner and vast resource to leverage political influence. For example, it offered the NHS (National Health Service) one billion pounds to help smokers switch to alternatives if the UK relaxed European Union (EU) regulations on e-cigarettes and heated tobacco products post-Brexit, a proposal known as the Tobacco Transition Fund (which the UK government rejected). ${ }^{44}$

Most recently, PMI capitalised on the COVID-19 pandemic to propagate its transformation narrative. ${ }^{45}$ Efforts ranged from a global rollout of corporate social responsibility activities, focused on donations to hospitals and crisis centres, to investing in COVID-19 vaccine development through PMI's part-ownership of biopharmaceutical company Medicago. ${ }^{46} 47$ PMI's chairman described the investment as 'part of our new course, based on science, technology and innovation'. ${ }^{48}$ Medicago went on to secure a partnership with the Government of Canada ${ }^{47}$ contravening Article 5.3 of the Framework Convention on Tobacco Control (FCTC). PMI also used messaging around the pandemic to boost sales, through offers of free HTPs, free contactless home delivery with waived ID validation and matched COVID-19 donations based on points accumulated iqos purchases. ${ }^{49}$

\section{Information management}

As part of its 2014 10-year corporate affairs plan, ${ }^{28}$ PMI set out to 'establish the concept of harm reduction as legitimate public policy in tobacco regulation' and 'establish the legitimacy of tobacco companies to be a part of the regulatory debate ['part of the solution']' (figure 1). 
Table 1 Timeline of key political activity in harm reduction involving the company currently known as Philip Morris International (including when working alongside other TTCs)

\begin{tabular}{|c|c|c|}
\hline Date & Action & Instrumental strategy \\
\hline 1953 & $\begin{array}{l}\text { Philip Morris-funded TIRC launched. TIRC promises to provide } \\
\text { 'aid and assistance to the research effort into all phases of tobacco use and health', }{ }^{114} \text { but was in practice first of a string of } \\
\text { organisations created for PR purposes, 'to convince the public that the hazards of smoking had not been proven'.115 }\end{array}$ & IM \\
\hline 1972 & $\begin{array}{l}\text { Tobacco Institute VP of Public Relations calls for proffering new explanations for ill health among smokers, including heredity and } \\
\text { stress. }{ }^{117}\end{array}$ & IM \\
\hline 1994 & Industry executives testify before US Congress that nicotine is not addictive despite having evidence it was since the 1960 s. $^{116}$ & $\mathrm{RM}, \mathrm{IM}$ \\
\hline 1995 & Philip Morris initiates Project Sunrise to form relationships with 'moderate' TC groups. ${ }^{70}$ & $\mathrm{CM}$ \\
\hline By 2000 & $\begin{array}{l}\text { Several major tobacco companies acknowledge on their websites that smoking can be addictive and harmful, presenting their carefully } \\
\text { worded statements to suggest higher standards of corporate responsibility. }{ }^{119}\end{array}$ & $\mathrm{RM}$ \\
\hline 2017 & PMI launches Foundation for a Smoke-Free World. ${ }^{16}$ & $\mathrm{IM}, \mathrm{CM}$ \\
\hline 2018 & PMI announces its goal is to achieve a 'smoke-free future'. ${ }^{16}$ & $\mathrm{RM}$ \\
\hline 2019 & $\begin{array}{l}\text { PMI offers } 1 \text { billion pounds to NHS as part of its 'tobacco transition fund' in exchange for the lifting of restrictions on advertising and } \\
\text { marketing of iqosand e-cigarettes. }{ }^{121}\end{array}$ & $\mathrm{CM}$ \\
\hline 2019-21 & $\begin{array}{l}\text { PMI publishes 'White Papers' on public health science and trust and holds events on public trust in science in conjunction with Industry } \\
\text { Transformation Coalition. }{ }^{45} 61122123\end{array}$ & $\mathrm{IM}, \mathrm{RM}, \mathrm{CM}$ \\
\hline
\end{tabular}

This timeline presents a sample of key developments and does not aim to be comprehensive.

CM, Coalition Management; IM, Information Management; PMI, Philip Morris International; RM, Reputation Management; TC, Tobacco Control; TIRC, Tobacco Industry Research Committee; TTC, transnational tobacco companies; VP, Vice-President.

This plan has been operationalised in a multifaceted information management campaign, part of over $\$ 50$ million spent over the past 6 years in marketing and research costs. ${ }^{50}$ Three key strategies have emerged in which PMI attempts to control everything from the science on HTPs, to the media discourse about harm reduction.

First, building on the industry's earlier tactical co-option of harm reduction terminology, ${ }^{27} \mathrm{PMI}$ is now attempting to redefine the concepts 'smokefree' (away from the complete absence of tobacco products) and 'quitting' (away from ending the use of tobacco and nicotine products). Its presentation of iqosas 'smokefree' may not be entirely accurate, due to the pyrolysis that occurs when the tobacco is heated. ${ }^{51} 52$ Similarly, PMI publishes estimates of 'quitting' based on the number of people who have 'switched' to iqos, even for a brief period, including dual users alongside cigarettes. ${ }^{16}$ PMI's 'harm reduction equation' suggests a broader attempt to redefine harm reduction (figure 2). Although there is no single definition of harm reduction, definitions generally acknowledge the need to reduce harm not only for the individual user but within the community and 

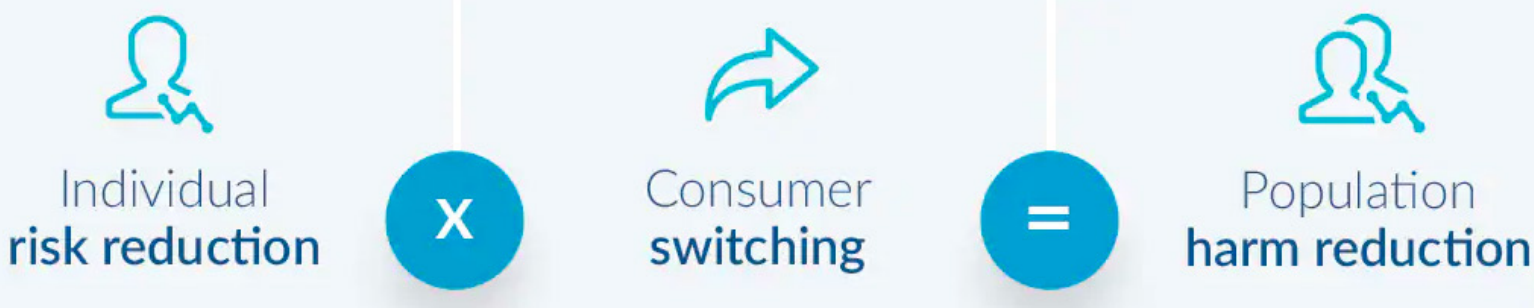

Figure 2 Philip Morris International harm reduction equation. ${ }^{124}$

society in which they live. ${ }^{53-57}$ PMI's equation instead focuses just on individual smokers using new products to 'switch' (notably not 'quit'), positioned as equivalent to proven population-based tobacco control measures. While moving smokers from a higher to a lower risk product will achieve significant health benefit, this equation overlooks concerns and evidence that, in some jurisdictions, wide availability and promotion of new products will lead to uptake among never smokers. ${ }^{58-60}$

Second, PMI is increasingly controlling the science through its internally conducted and directly funded science (promoted through the 'PMI Science' website) and that funded by the Foundation for a Smokefree World (FSFW), created by PMI with a billion-dollar pledge in 2017. ${ }^{61}{ }^{62}$ Reminiscent of the disbanded TIRC (Tobacco Industry Research Committee) and CIAR (Center for Indoor Air Research), FSFW has been accused of operating as little more than a PR arm of the tobacco company. ${ }^{63}$ PMI and FSFW, operating together, are propagating rhetoric that lies in stark contrast to reality (table 2).

Third, the company is attempting to further control discourse on harm reduction and ensure favourable representation of its transformation and products by influencing the media. It has invited journalists on all-expenses paid trips to attend science tours at its labs, placed large advertorials in broadsheets ${ }^{64}$ and is funding PR and media companies to promote both the company and switching to alternative products. ${ }^{16}$ While it promotes this sympathetic media coverage, it opposes research findings and media coverage that critiques or contradicts its messages. ${ }^{61}$

\section{Coalition management}

In addition to FSFW and other established industry allies, ${ }^{61} \mathrm{PMI}$, with other controversial industries (oil/gas/unhealthy food), has recently formed the Industry Transformation Coalition, a corporate public relations organisation positioning industry as a 'catalyst for good' and lobbying for technological solutions for the world's problems. ${ }^{65}$ FSFW has also funded International Network of Nicotine Consumer Organisations (INNCO), an umbrella organisation with 40 listed members and affiliates (industry-linked and independent) which publicise many of the same harm reduction messages promoted by TTCs. ${ }^{66} 67$ Such networks represent a mobilisation of the company's corporate affairs plan, leveraging 'third party coalition building' to create an 'alliance of credible messengers'. ${ }^{28}$

PMI has attempted to exploit divisions in the public health community over harm reduction and, along with front groups and allies, is attempting to tarnish the reputation of the global tobacco control community. ${ }^{14} 166869$ PMI's targeting of individuals and organisations within tobacco control has roots in project sunrise, initiated in 1995 (table 1), where PMI questioned the credibility and integrity of some in tobacco control, while

Table 2 Transformation claims made by PMI on harm reduction (the rhetoric vs the reality)

Philip Morris International's claim
'We're trying to give up cigarettes' and want to help smokers who are seeking a
'better alternative'. ${ }^{125} 126$
'We have reduced our global cigarette sales by getting smokers to switch to
iqos'
'iqosis a smokefree product'133
'The FDA authorised our electronically heated tobacco system, iqos, as a modified
risk tobacco product'.
(We) 'do not, and will not, market or sell our products to youth'137

(We) 'do not, and will not, market or sell our products to youth'137

'We support tobacco control regulations' 50

\section{The reality}

$\mathrm{PMI}$ is still marketing cigarettes, redesigning pre-existing cigarette brands and introducing new ones and, in 2020, made US\$19 bn in gross profit from cigarette sales. ${ }^{16} 50$ 127-132

The change in PMI's mean annual absolute decline in cigarette sales indicate that PMI's current claimed reduction and 'aspirational targets' restate existing trends, rather than accelerate them. ${ }^{66}$

Research suggests that PMI is playing on terminology in making such claims and that iqos may in fact give off smoke and exposes users to higher levels of toxins than vaping products. ${ }^{51} 52$

FDA ruling said that PMI could say that iqos is a reduced exposure product but not reduced risk as reduced exposure does not necessarily translate into reduced risk. ${ }^{135} 136$

Marketing expertise suggests that iqosads appeal to youth as does PMI's use of social media influencer marketing. ${ }^{16138-140}$

Tobacco companies including PMI are still contesting evidence-based tobacco control policies (eg, standardised packaging, point of sale display bans, flavouring bans) that reduce smoking prevalence, particularly in LMICs. ${ }^{16141}$

These messages do not align with the actions of PMI-its iqosmarketing through social media influencers targets and appeals to youth. It also downplays the phenomenon of dual use when, in reality, most iqosusers continue to smoke cigarettes. ${ }^{16} 142-145$ 
working with others to promote favourable policy options. ${ }^{70}$ This strategy was re-emphasised in their 2014 corporate affairs plan which described their aim to 'amplify and leverage the debate on harm reduction'. ${ }^{28}$ PMI have since claimed that tobacco control research and advocacy is biased by charitable or philanthropic funding, ${ }^{43} 71$ that they are the victim of misinformation and 'sham science', ${ }^{73}$ and used social media to criticise people and organisations perceived as opposing its products and harm reduction claims. ${ }^{69}$ These challenges to the tobacco control community aim to fragment the usually unified voice of the tobacco control movement, muddying the waters in policy debates and distracting attention from effective tobacco control measures. $^{27} 7475$

\section{Case study 2: TTCs long-term 'victim and solution' strategy to define the narrative on illicit tobacco trade (1990s-2021)}

In the late 1990s, internal industry documents demonstrated that facilitating the smuggling of their own products had been a core part of TTCs' global business strategies for decades. ${ }^{76-80}$ This led to a series of investigations and legal action and within a relatively short-time TTCs had been exposed as suppliers of illicit tobacco. ${ }^{15}{ }^{81-84}$ In response, the Protocol to Eliminate Illicit Trade in Tobacco Products was developed, coming into force in September 2018, aiming to eliminate illicit tobacco trade through a package of measures taken by countries acting cooperatively.

Recognising the threat to profitability from loss of this avenue for sales and profits, tobacco companies began to publicly position themselves as both victims of, and solutions to, the illicit tobacco trade. This despite evidence that tobacco companies continue to facilitate the illicit trade of their own products. ${ }^{15} 85$ TTC promotion of the inadequate and inefficient industry-developed tracking and tracing system Codentify further serves to ensure that illicit trade continues. ${ }^{158687}$ TTCs have come to dominate the debate around illicit tobacco trade effectively setting the agenda on the topic. ${ }^{15}$ This poses a substantial risk to accurate understandings of the illicit tobacco trade and, more broadly, of tobacco industry regulatory capture and neutralisation of effective measures to address tobacco smuggling. Our analysis shows how TTCs have used their vast resources to reach key stakeholders at global level with subsequent policy impacts at regional and national levels, using three main and inter-linked instrumental strategies over two decades (table 3). Below, we consider each in turn.

\section{Reputation management}

TTCs have engaged in a global PR campaign to promote their primary discursive strategy-that the industry has changed and is a necessary part of the solution for illicit trade (table 4). Despite data indicating that approximately two thirds of the global illicit tobacco market between 2007 and 2016 consisted of product smuggled from the supply chains of tobacco companies, tobacco companies now emphasise the presence of other products (counterfeits and illicit white cigarettes) on the illicit market to portray the illicit tobacco trade as detrimental to their profits. $^{1588}$ Tobacco companies appear to have been successful in presenting themselves as victims, largely through extensive efforts to ingratiate themselves with authorities tasked with addressing illicit trade, including through large donations and

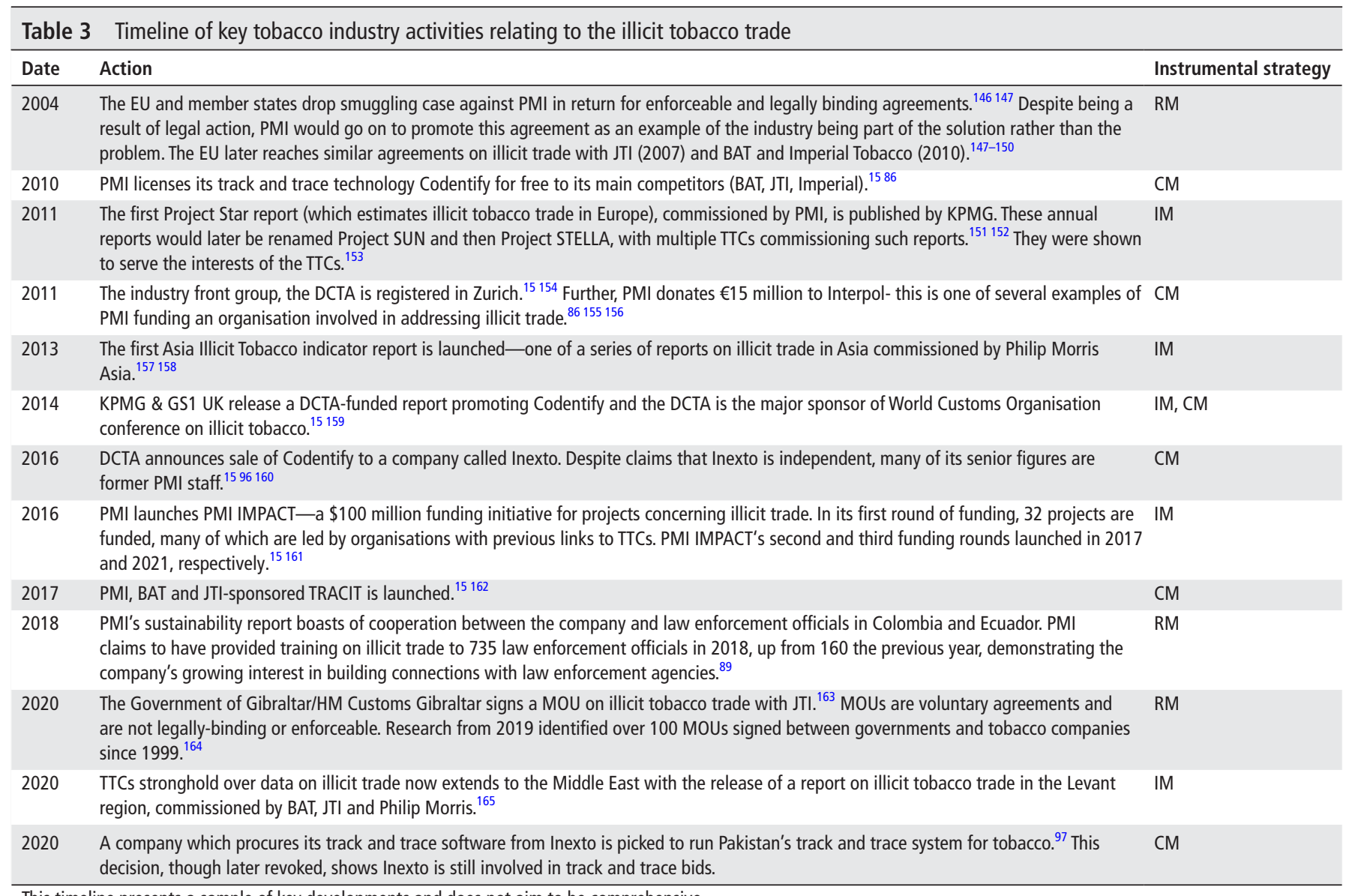

This timeline presents a sample of key developments and does not aim to be comprehensive.

BAT, British American Tobacco; CM, Coalition Management; DCTA, Digital Coding and Tracking Association; EU, European Union; GS1, Global Standards 1; IM, Information

Management; JTI, Japan Tobacco International; MoU, Memorandum of Understanding; RM, Reputation Management; TRACIT, Transnational Alliance to Combat Illicit Trade. 
Table 4 Claims made by TTCs on illicit trade (the rhetoric vs the reality)

\begin{tabular}{|c|c|}
\hline TTC claims & The reality \\
\hline $\begin{array}{l}\text { Counterfeits and cheap/illicit whites make up much of the } \\
\text { illicit cigarette market. }{ }^{166} 167\end{array}$ & $\begin{array}{l}\text { Approximately two thirds of the global illicit tobacco market between } 2007-2016 \text { consisted of product smuggled } \\
\text { from the supply chains of tobacco companies, while only } 2 \%-7 \% \text { were counterfeits. }{ }^{15}\end{array}$ \\
\hline $\begin{array}{l}\text { Tax and other tobacco control policies are key drivers of illicit } \\
\text { trade. }{ }^{168}\end{array}$ & $\begin{array}{l}\text { Taxes only play a minor role in illicit tobacco trade, with evidence indicating that illicit trade tends to be larger in } \\
\text { countries with lower cigarette prices than those with higher prices and that strength of monitoring, enforcement } \\
\text { and governance having greater influence. }\end{array}$ \\
\hline $\begin{array}{l}\text { Governments should form partnerships with the TTCs to stop } \\
\text { illicit trade. }{ }^{171}\end{array}$ & $\begin{array}{l}\text { Partnerships between government bodies and tobacco companies most often take the form of memorandums } \\
\text { of understanding which are neither enforceable nor legally binding. Nor have they been shown to reduce illicit } \\
\text { trade. }\end{array}$ \\
\hline
\end{tabular}

TTC, transnational tobacco companies.

providing anti-illicit trade training events for law enforcement officials in various countries (table 4). ${ }^{159}$

\section{Information management}

Such efforts are supported by a well-funded information management strategy where TTCs have positioned themselves as a major provider of data on illicit trade. Over the past two decades, TTC-commissioned reports have become the primary source of data on illicit tobacco throughout most of the world. ${ }^{90-92}$ These reports have often criticised been for lacking transparency and inadequate methodologies, producing inflated estimates of illicit tobacco trade and downplaying or concealing the presence of tobacco companies' product on the illicit market. ${ }^{91}$ These reports-often regional and well-publicised-allow TTCs to define the problem of illicit tobacco trade (eg, its nature, scale and drivers) and to garner media interest, ensuring the industry's 'victim and solution' messaging dominates media coverage of illicit from global to local levels (table 4). Similarly, by funding international conferences and reports on track and trace technology, TTCs have promoted their own track and trace system, Codentify, seeking to have this implemented over other systems without industry links. ${ }^{15} 9394$ These efforts ultimately increase TTCs access to regulators and policy makers.

\section{Coalition management}

Tobacco companies use of front groups to perpetuate arguments that tobacco control policies drive illicit trade is well documented. ${ }^{95}$ However, over the past decade, we have seen increasingly covert and deceptive strategies to try and undermine measures to address illicit trade. ${ }^{1596}$ This includes TTCs collaborative, long-term strategy to promote their industry-controlled and ineffective Codentify system to governments ${ }^{15}$ (table 3 ). While coordinated efforts to influence tracking and tracing implementation at national level used global TTC messaging around illicit trade, often through a complex system of third parties, front groups and media spokespeople (including ex-law enforcement). ${ }^{15} 96-98$ Such groups also present TTCs positions in policy consultations and elsewhere, often without disclosing their links to these companies. ${ }^{1598}$

\section{DISCUSSION}

This paper set out to examine TTCs' long-term policy influence strategies which the literature hitherto has rarely examined in detail. It shows that in addition to their reactive efforts to oppose almost every effective tobacco control policy country by country, TTCs engage in long-term, proactive strategies to promote their corporate interests and goals. Using two case studies, we show that three mutually reinforcing instrumental strategies dominate in the longer-term-reputation management, coalition management and information management. These instrumental strategies work synergistically to propagate one over-riding discursive strategy-'we've changed, we are part of the solution'-despite clear evidence in both case studies that this is not the case. In this way, tobacco companies attempt to redefine the dominant narrative away from a 'pariah' industry which should be systematically excluded from decision making (as per FCTC Article 5.3) towards one central to solving the tobacco epidemic.

We also note that in redefining the dominant narrative, TTCs are also attempting to redefine key concepts and shape the language of the debate and responsibilities for action. This includes redefining harm reduction, 'smokefree' and 'quitting'. Similarly, the illicit case study suggests that TTCs have attempted to redefine illicit tobacco as largely a problem created by other actors-counterfeit or illicit whites produced by criminal enterprises, rather than the TTCs own product. ${ }^{15}$ In both cases, the TTCs' resource advantage enables themto do this- to monopolise data, to publish extensive advertorials and 'white papers' and host events-all of which secure extensive media coverage, enabling TTCs to dominate debates and reach key audiences. In short, these longer-term strategies exert covert power by framing the parameters of debate, reshaping norms and beliefs around the tobacco industry and tobacco control, legitimising TTC positions and ultimately seeking to make TTCs' agendas appear desirable to policymakers and the tobacco control community seem misguided.

It is notable that the dominant long-term instrumental strategies identified are indirect (and covert) rather than direct (and overt). This likely reflects the success of tobacco control and of Article 5.3 in 'demonising' the industry and explains TTCs' significant focus on reputation management and coalition management in both case studies. Coalition management strategies have always been a means to exert hidden power, but these webs of influence have become increasingly complex and opaque. For example, through the umbrella organisation INNCO, TTC-funded third parties and independents are enmeshed, serving both to camouflage TTC influence where it occurs and increase exposure to their messaging. Similarly, Codentify, initially being promoted through one front group, has now been sold to another company (with multiple ex-PMI employees) which licenses software to other companies, which in turn apply for national track-andtrace tenders, making it hard to trace industry links. ${ }^{969}$ Our findings also suggest that these long-term strategies primarily operate at global level and are then leveraged at the national level, with the TTCs' global efforts setting the stage on which national policies are negotiated. This may prove particularly problematic in countries where the tobacco industry is not yet delegitimised, and civil society is less well-resourced and hence less able to counter the TTCs and their narrative. Overall, our findings demonstrate the need to critically review TTCs' current actions and claims in the context of evidence for extensive 
engagement in strategies aimed to build credibility, secure policy influence and reboost declining sales and profits, generally at the expense of population health.

\section{LIMITATIONS}

This paper has several limitations. First, TTCs activities are multiple and are often hidden. Extensive searches were conducted, but we were restricted to publicly available data and, while this includes detailed leaked industry documents, it likely provides a limited view of activities in each case study, particularly at national level, in countries without English as an official language, and across all TTCs. Further case studies are needed to see if the strategies identified in harm reduction and illicit trade are generalisable across the spectrum of industry activity.

\section{Challenges and recommendations}

Our findings have implications for tobacco control. First, they demonstrate the importance of identifying and addressing the TTCs' long-term influence strategies which are carefully coordinated at the global level yet which, by reshaping norms and beliefs, can have wider reaching impacts. The FCTC amply demonstrates the global ambition and reach of tobacco control. Yet, the FCTC, and tobacco control more generally, are largely operationalised at the national level where, in part due to resource constraints, advocacy efforts to address tobacco industry interference often focus on short-term policy opportunities. While national and regional work remain an essential entry point to understand and counter TTC strategies, a global focus could allow tracking and identification of new patterns of TTC activity or 'norms' that need countering and provide a means of bringing public health messages to, and countering TTC messages in, specific global settings. Such efforts would be closely coordinated with and support regional and national work, enabling efficiencies to be realised. Second, and closely linked to this, TTCs' overwhelming focus on renormalisation through reputation management shows that tobacco industry denormalisation, for which there is substantial evidence, should be considered an essential tobacco control measure. ${ }^{100}$ The implementation of a global denormalisation campaign could be one such effort, which could then be leveraged at regional and national levels. Third, the dominant use of coalition management strategies and the increasing use of third parties and what can be described as 'dark influence webs' suggests we must become more adept at exposing TTC third parties. This requires new research methods, including novel digital methods to identify likely front groups. This is, however, complex and time consuming and we therefore need to shift the onus to others: participation in policy events and consultations should require full disclosure of funding for participants and submitted evidence-simply declaring 'no COI' or no funding is insufficient. The importance of Article 5.3 cannot be overstated, and effective transparency and lobbying registers remain essential. Finally, growing TTC control of data and evidence, which enables it to shape norms, will hinder progress in all areas unless addressed. For example, the potential for novel products to contribute to tobacco control is hindered by the fact that research on such products is dominated by TTCs with an appalling history of research misconduct which emerging evidence suggests may be being repeated, and a vested interest in showing its products are safe. ${ }^{101-103}$ Ways to address this include through a database of authors' and editors' conflicts of interest which can help overcome the documented failure to declare interests within specific papers and alternative means of raising research funds from corporations while protecting that research from vested interests, issues explored elsewhere. ${ }^{101} 104$ Open discussion and trust among the public health community will enable information on TTC conduct to be considered alongside emerging science on new products and their potential benefits and harms - only with this combination of evidence can the most effective policy decisions be made.

More broadly, there are lessons for efforts to address the commercial determinants of health, given the clear commonalities in underlying drivers and strategies already demonstrated across unhealthy commodity industries. ${ }^{105-107}$ Those working in alcohol and food policy should seek from the outset to address these global long-term influence strategies and not just focus on the immediate national level challenges. More broadly, we need to recognise that until we address underlying system drivers, progress will remain limited. ${ }^{107} 108$ The TTCs' growing use of increasingly opaque 'webs of influence' indicates this problemTTCs have used their resource advantage to adapt to and counter attempts to increase transparency in policymaking. The public health community must therefore work collectively to push for more radical structural and systems change to address the commercial determinants of health. This might include accountability mechanisms such as ensuring corporations pay for the costs of the harm caused by the sale of harmful products, amending corporate regulation to reduce the dominant focus

What this paper adds

- To date most literature on tobacco industry policy influence focuses on the TTC's reactive efforts to oppose tobacco control policy, but TTCs also engage in long-term, proactive policy influence strategies to promote their corporate interests and goals. This paper sought to examine TTCs longterm influence strategies using two case studies.

- In both case studies we found the industry draws on its immense material and ideational power to commission and publish misleading evidence, reports, advertorials and other outputs that serve its interests (information management), to establish and fund organisations that promote the industry's messaging while often purporting to be independent or are meant to hold industry to account (coalition management), and to host events and secure media coverage that promote its messaging to key audiences (reputation management).

- These long-term strategies serve to redefine key concepts and dominant narratives, reframe the parameters of debate and reshape norms to the TI. Collectively they serve to position the tobacco industry as part of the solution to tobacco control and tobacco smuggling, to create confusion and division, and to undermine Article 5.3.

- These actions are globally coordinated and set the stage on which national policies are negotiated, thereby widely stymying progress.

- The tobacco control community needs to pay greater attention to these efforts. Countering them will require a global focus which must include awareness raising and tobacco industry denormalisation, new ways to fund research, better requirements for transparency in research and policy, and innovative research to identify industry third parties. Above all, these ongoing problems despite decades of progress in tobacco control should serve as a lesson for efforts to address the commercial determinants of health and indicate the need for structural solutions to address corporate power. 
on profit and/or change the rules on limited liability, and wider changes to the global political and economic system that have increased corporate power and influence.

Twitter Thomas R Hird @ThomasRHird, Allen William Andrew Gallagher @ AllenGallagher_, Pascal A Diethelm @pdiethelm and Anna B Gilmore @BathTR

Contributors $A B G$ and TRH conceived the idea for the paper. RE provided critical feedback on the idea. TRH, AWAG, KE-R, MZ, SD and PAD collected data for analysed and drafted the case studies. TRH and AG drafted the overall paper. All authors contributed to editing of the paper.

Funding TRH, AWAG, KE-R, MZ, SD and ABG acknowledge the support of Bloomberg Philanthropies' Stopping Tobacco Organizations and Products funding (http://www.bloomberg.org/).

Competing interests None declared.

Patient consent for publication Not applicable.

Ethics approval This study does not involve human participants.

Provenance and peer review Commissioned; externally peer reviewed.

Author note This paper is dedicated to the memory of Dr Mateusz Zatoński.

ORCID iDs

Thomas R Hird http://orcid.org/0000-0003-3423-4617

Allen William Andrew Gallagher http://orcid.org//0000-0002-3669-0360

Richard Edwards http://orcid.org/0000-0003-2264-9823

Anna B Gilmore http://orcid.org/0000-0003-0281-1248

\section{REFERENCES}

1 Davis RM, Smith R. Addressing the most important preventable cause of death. BMJ 1991:303:732-3.

2 Callard C, Collishaw NE. Exploring vector space: overcoming resistance to direct control of the tobacco industry. Tob Control 2012;21:291.

3 World Health Organization. Impact assessment of the who FCTC: report by the expert group. conference of the parties to the who framework convention on tobacco control: who framework convention on tobacco control, 2016.

4 Fooks GJ, Smith J, Lee K, et al. Controlling corporate influence in health policy making? an assessment of the implementation of article 5.3 of the world Health organization framework convention on tobacco control. Global Health 2017:13:12.

5 World Health Organization. WHO report on the global tobacco epidemic 2021: addressing new and emerging products. Geneva: World Health Organization, 2021.

6 Sheikh ZD, Branston JR, Gilmore AB. Tobacco industry pricing strategies in response to excise tax policies: a systematic review. Tob Control 2021:tobaccocontrol2021-056630.

7 Reitsma MB, Flor LS, Mullany EC, et al. Spatial, temporal, and demographic patterns in prevalence of smoking tobacco use and initiation among young people in 204 countries and territories, 1990-2019. Lancet Public Health 2021;6:e472-e481.

8 Kingdon JW, Stano E. Agendas, alternatives, and public policies: little, brown Boston, 1984.

9 Gilmore $A B$, Fooks G, Drope J, et al. Exposing and addressing tobacco industry conduct in low-income and middle-income countries. Lancet 2015;385:1029-43.

10 Ulucanlar S, Fooks GJ, Gilmore AB. The policy dystopia model: an interpretive analysis of tobacco industry political activity. PLoS Med 2016;13:e1002125.

11 Malone RE. The tobacco industry, 2020: a snapshot. Tob Control 2020;29:e1-3.

12 Savell $\mathrm{E}$, Gilmore AB, Fooks $\mathrm{G}$. How does the tobacco industry attempt to influence marketing regulations? A systematic review. PLoS One 2014;9:e87389.

13 Smith KE, Savell E, Gilmore AB. What is known about tobacco industry efforts to influence tobacco Tax? A systematic review of empirical studies. Tob Control 2013;22:e1.

14 Kalra A, Bansal P, Wilson D. Inside Philip Morris' campaign to subvert the global anti-smoking treaty. Reuters, 2017. Available: https://www.reuters.com/investigates/ special-report/pmi-who-fctcl

15 Gilmore AB, Gallagher AWA, Rowell A. Tobacco industry's elaborate attempts to control a global track and trace system and fundamentally undermine the illicit trade protocol. Tob Control 2019;28:127-40.

16 Evans-Reeves K, Gilmore A. Addiction at any cost. Philip Morris international uncovered, 2020. Available: https://exposetobacco.org/pmi-uncovered/

17 Evans-Reeves KA, Hatchard JL, Gilmore AB. 'It will harm business and increase illicit trade': an evaluation of the relevance, quality and transparency of evidence submitted by transnational tobacco companies to the UK consultation on standardised packaging 2012. Tob Control 2015;24:e168-77.

18 Matthes BK, Lauber K, Zatoński M, et al. Developing more detailed taxonomies of tobacco industry political activity in low-income and middle-income countries: qualitative evidence from eight countries. BMJ Glob Health 2021;6: 004096.

19 Nagelhout G, van Straaten B, Poole N. Factsheet: literature review of tobacco industry responses to tobacco control measures: Stichting Instituut voor Onderzoek naar Leefwijzen \& Verslaving (IVO), 2020. Available: https://ivo.nl/publicaties/ facstheet-literature-review-of-tobacco-industry-responses-to-tobacco-controlmeasures/

20 Forster N. The analysis of company documentation. In: Cassell C, Symon G, eds. Qualitative methods in organizational research: a practical guide. California: Sage Publications, 1997

21 Lincoln Y, Guba E. Naturalistic inquiry. California: Sage Publications, 1985.

22 DOLL R, HILL AB. Smoking and carcinoma of the lung; preliminary report. Br Med J 1950:2:739-48.

23 ed., Benowitz N. Compensatory smoking of low-yield cigarettes. In: Risks associated with smoking cigarettes with low machine-measured yields of TAR and nicotine: U.S. department of health and human services. National Cancer Institute, 2001.

24 Pollay RW, Dewhirst T. The dark side of marketing seemingly "Light" cigarettes: successful images and failed fact. Tob Control 2002;11 Suppl 1:118-31.

25 Fairchild A, Colgrove J. Out of the ashes: the life, death, and rebirth of the "safer" cigarette in the United States. Am J Public Health 2004;94:192-204.

26 Peeters S, Gilmore AB. Transnational tobacco company interests in smokeless tobacco in Europe: analysis of internal industry documents and contemporary industry materials. PLoS Med 2013:10:e1001506.

27 Peeters S, Gilmore AB. Understanding the emergence of the tobacco industry's use of the term tobacco harm reduction in order to inform public health policy. Tob Control 2015;24:182-9.

28 Philip Morris International. 10 year corporate affairs objectives and strategies. Reuters, 2014

29 British American Tobacco. Building the enterprise of the future" performance summary 2020. London: British American Tobacco, 2021. https://www.bat.com/ar/ 20201

30 Altria. Our 10-year vision: Altria, 2021. Available: https://www.altria.com/en/aboutaltria/our-10-year-vision

31 Imperial Brands. Our strategy London: imperial brands, 2021. Available: https://www. imperialbrandsplc.com/about-us/Our-strategy.html

32 British American Tobacco. Our purpose and strategy. London: British American Tobacco, 2021. https://www.bat.com/strategy

33 Hodgson C. The maker of Marlboro took out a full-page ad saying its New Year's resolution is to 'give up cigarettes'. Business Insider 20183 January 2018. Available: https://www.businessinsider.com/philip-morris-international-give-up-cigarettesadvert-2018-1?r=US\&IR=T

34 Philip Morris International. It's time to unsmoke: Why now is the time to act 2019 . Available: https://www.pmi.com/our-initiatives/itstime/its-time-to-unsmoke-why-now

35 Philip Morris International. Unsmoke your mind, 2019. Available: https://www. unsmokeyourmind.com/en/

36 Philip Morris International. Heat not burn technology - FAQs, 2021. Available: https://uk.iqos.com/myiqos/get-support/fags/heat-not-burn-technology

37 Fried ND, Gardner JD. Heat-not-burn tobacco products: an emerging threat to cardiovascular health. Am J Physiol Heart Circ Physiol 2020;319:H1234-9.

38 Dewhirst T. Co-optation of harm reduction by big tobacco. Tob Control 2021;30:e1-3.

39 Rowell A. Big tobacco is funding the anti-smoking lobby - but leaked documents reveal the real reason why, 2018. Available: https://theconversation.com/bigtobacco-is-funding-the-anti-smokinglobby-but-leaked-documents-reveal-therealreason-why-93087

40 Malone RE. Tobacco industry shoving its snout under the un tent flap. Tob Control 2019:28:479-80

41 Jovičić J. PMI presents new white paper during this year's world economic forum in Davos. Diplomacy \& Commerce 201925 January 2019. Available: http://www. diplomacyandcommerce.rs/pmi-presents-new-white-paper-during-this-yearss-worldeconomic-forum-in-davos/

42 Hickman A. Cannes Lions slammed for placing Philip Morris on good track Campaign Live 2019, 2019. Available: https://www.campaignlive.co.uk/article/cannes-lionsslammedplacing-philip-morris-good-track/1588443

43 Philip Morris International. World Health organization report on tobacco fails people who currently smoke, 2019. Available: https://www.pmi.com/media-center/pressreleases/press-release-details/?newsld $=2144$

44 Chapman B. World's biggest cigarette company offered tobacco products to doctors and nurses to mark NHS 70th birthday. The Independent, 2018. Available: https:// www.independent.co.uk/news/business/news/philip-morris-tobacco-products-nhsanniversary-smoking-smoke-free-cigarettes-a8455141.htm

45 Philip Morris International. From upset to reset: trust in a COVID world. PMI white paper winter 2020/2021. New York: Philip Morris International, 2021. https://www. pmi.com/resources/docs/default-source/default-document-library/pmi-whitepapertrust-covid-world.pdf?sfvrsn=76edddb4_0

46 Zatoński M, Gilmore A, Hird T. The two faces of the tobacco industry during the COVID-19 pandemic. Tob control, 2020. Available: https://blogs.bmj.com/tc/2020/ 05/10/the-two-faces-of-the-tobacco-industry-during-the-covid-19-pandemic/

47 Cohen J, Chapman S. Philip Morris and the government of Canada collaborate on COVID-19 vaccine development. Tob control, 2020. Available: https://blogs.bmj.com/ tc/2020/11/21/philip-morris-and-the-government-of-canada-collaborate-on-covid19-vaccine-development/ 
48 Philip Morris International. Medicago develops a plant-based vaccine for coronavirus, 2020. Available: https://www.pmi.com/media-center/news/medicago-develops-aplant-based-vaccine-for-coronavirus

49 Organized Crime and Corruption Reporting Project (OCCRP). Pandering to a pandemic, 2020. Available: https://www.occrp.org/en/loosetobacco/blowingunsmoke/pandering-to-pandemic

50 Philip Morris International. 2020 annual report: together. forward, 2020. Available: https://www.pmi.com/resources/docs/default-source/investor_relation/pmi_2020 annualreport.pdf?sfvrsn=402b8eb4_2

51 Auer R, Concha-Lozano N, Jacot-Sadowski I, et al. Heat-Not-Burn tobacco cigarettes: smoke by any other name. JAMA Intern Med 2017;177:1050-2.

52 Vivarelli F, Canistro D, Cirillo S, et al. Unburned tobacco cigarette smoke alters rat ultrastructural lung airways and DNA. Nicotine Tob Res 2021;23:2127-2134.

53 Marlatt GA. Harm reduction: come as you are. Addict Behav 1996;21:779-88.

54 Newcombe R, O'Hare P, Matthews A. The reduction of drug related harm: Routledge London, 1992

55 Canadian Centre on Substance Use and Addiction. Harm reduction: What's in a name? Ottawa, ON 2008:10. Available: https://ccsa.ca/sites/default/files/2019-05/ ccsa0115302008e.pdf

56 Lenton S, Single E. The definition of harm reduction. Drug Alcohol Rev 1998;17:213-9.

57 Newcombe R. High time for harm reduction. Druglink, 1987: 10-11. https://www. drugwise.org.uk/wp-content/uploads/High-time-for-harm-reduction.pdf

58 Bandi P, Cahn Z, Goding Sauer A, et al. Trends in e-cigarette use by age group and Combustible cigarette smoking histories, U.S. adults, 2014-2018. Am J Prev Med 2021;60:151-8.

59 Dutra LM, Glantz SA. High international electronic cigarette use among never smoker adolescents. J Adolesc Health 2014;55:595-7.

60 McMillen R, Klein JD, Wilson K, et al. E-Cigarette use and future cigarette initiation among never smokers and relapse among former smokers in the path study. Public Health Rep 2019;134:528-36.

61 Tobacco Tactics. Philip Morris international, 2021. Available: https://tobaccotactics. org/wiki/philip-morris-international/

62 Philip Morris International. Pmi science, 2021. Available: https://www.pmiscience. $\mathrm{com} /$

63 Legg T, Peeters S, Chamberlain P, et al. The Philip Morris-funded foundation for a smoke-free world: Tax return sheds light on funding activities. Lancet 2019:393:2487-8

64 Moodie C, Hammond D, Bauld L. Philip Morris international: a new year's resolution Tob Control 2018:27:e79.

65 Tobacco Tactics. The industry transformation coalition, 2021. Available: https:// tobaccotactics.org/wiki/the-industry-transformation-coalition/

66 Edwards R, Hoek J, Karreman N. Tobacco industry transformation: reality or fantasy? Tob Control.

67 Tobacco Tactics. International network of nicotine consumer organisations (INNCO), 2021. Available: https://tobaccotactics.org/wiki/international-network-of-nicotineconsumer-organisations-innco/

68 Philip Morris International. World Health organization fails to put science at the core of public policy, 2019. Available: https://www.pmi.com/media-center/press-releases/ press-release-details/?newsld $=21441$

69 Robertson L, Joshi A, Legg T. Exploring the Twitter activity around the eighth meeting of the conference of the parties to the who framework convention on tobacco control. Tob Control 2022;31:50-6.

70 McDaniel PA, Smith EA, Malone RE. Philip Morris's project Sunrise: weakening tobacco control by working with it. Tob Control 2006;15:215-23.

71 Philip Morris International. Prohibition at any cost? 2020. Available: https://www. pmi.com/our-initiatives/prohibition-at-any-cost

72 Philip Morris International. We cannot let misinformation get in the way of progress, 2021. Available: https://www.pmi.com/media-center/news/we-cannot-letmisinformation-get-in-the-way-of-progress

73 Philip Morris International. Unsmoke your mind: pragmatic answers to tough questions for a smoke-free future, 2020. Available: https://pmidotcom3-prd.s3. amazonaws.com/docs/default-source/initiatives/unsmoke-your-mind-whitepaper.pdf? sfvrsn=7b455cb4_2

74 Bialous SA, Glantz SA. Heated tobacco products: another tobacco industry global strategy to slow progress in tobacco control. Tob Control 2018;27:s111.

75 Mathers A, Hawkins B, Lee K. Transnational tobacco companies and new nicotine delivery systems. Am J Public Health 2019;109:227-35.

76 Joossens L, Raw M. Cigarette smuggling in Europe: who really benefits? Tob Control 1998;7:66-71

77 Joossens L, Raw M. How can cigarette smuggling be reduced? BMJ 2000:321:947-50.

78 Nakkash R, Lee K. Smuggling as the "key to a combined market": British American Tobacco in Lebanon. Tob Control 2008:17:324-31.

79 Collin J, Legresley E, MacKenzie R, et al. Complicity in contraband: British American tobacco and cigarette smuggling in Asia. Tob Control 2004;13 Suppl 2:ii104-11.
80 Gilmore AB, McKee M. Moving East: how the transnational tobacco industry gained entry to the emerging markets of the former Soviet Union-part I: establishing cigarette imports. Tob Control 2004;13:143-50.

81 Home Affairs Committee. First report - tobacco smuggling, 2014. Available: https:// publications.parliament.uk/pa/cm201415/cmselect/cmhaff/200/20002.htm [Accessed 25 Jul 2017].

82 Beltrame J, Fairclough G. Canada sues R.J. Reynolds Tobacco for \$1 billion, Alleges smuggling plot. Wall Street Journal, 1999. Available: https://www.wsj.com/articles/ SB94579377624800941

83 United States district Court for the eastern district of new York. The European community, Plaintiff, V. RJR NABISCO, Inc., et al., defendants. Department of AMAZONAS, et al., Plaintiffs, V. Philip Morris companies, Inc., et al., defendants. New York: United States district Court, eastern district of new York, 2001. Available: http://uniset.ca/other/cs6/150FSupp2d456.html [Accessed 6 Nov 2017].

84 Hache T. Tobacco-Related litigation in Canada, 2010. Available: http://nsra-adnf. ca/wp-content/uploads/2016/07/Tobacco-related_Litigation_in_Canada_2010.pd [Accessed 25 Jul 2017]

85 KPMG. Illicit cigarette consumption in the EU, UK, Norway and Switzerland, 2021. Available: https://conveniencestores.se/images/kpmg-report-illicit-cigaretteconsumption-in-the-eu-uk-norway-and-switzerland-2020-results.pdf

86 Joossens L, Gilmore AB. The transnational tobacco companies' strategy to promote Codentify, their inadequate tracking and tracing standard. Tob Control 2014;23:e3.

87 Ross H, Eads M, Yates M. Why governments cannot afford Codentify to support their track and trace solutions. Tob Control 2018;27:706-8.

88 Ross H, Vellios N, Clegg Smith K, et al. A closer look at 'Cheap White' cigarettes. Tob Control 2016;25:527.

89 Philip Morris International. Sustainability report 2018, 2018. Available: https:// www.pmi.com/resources/docs/default-source/pmi-sustainability/pmisustainability-report-2018-low-res.pdf?sfvrsn=cada91b5_4 [Accessed 02 September 2019].

90 Gallagher A, Gilmore AB. Euromonitor international now accepts tobacco industry funding: a WIN for PMI at the expense of research on the tobacco industry. Blog: Tobacco Control, 2019. https://blogs.bmj.com/tc/2019/04/08/euromonitorinternational-now-accepts-tobacco-industry-funding-a-win-for-pmi-at-the-expenseof-research-on-the-tobacco-industry/

91 Gallagher AWA, Evans-Reeves KA, Hatchard JL, et al. Tobacco industry data on illicit tobacco trade: a systematic review of existing assessments. Tob Control 2019:28:334-45

92 Sandberg E, Gallagher AW, Alebshehy R. Tobacco industry commissioned reports on illicit tobacco trade in the eastern Mediterranean region: how accurate are they? East Mediterr Health J 2020;26:1320-2.

93 Tobacco Tactics. Tobacco smuggling, 2020. Available: https://tobaccotactics.org/wiki/ tobacco-smuggling/

94 Framework Convention Alliance, Sovereign Border Solutions. FCTC protocol to eliminate illicit trade in tobacco products: Guidebook on implementing article 8: Tracking \& tracing: Framework Convention Alliance, 2019. Available: https://fctc.org/ wp-content/uploads/2019/11/ITP-Guidebook-.pdf

95 Bialous S, Silva V. The tobacco industry and the illicit trade in tobacco products. Geneva: World Health Organization, 2016.

96 Gallagher AWA, Gilmore AB, Eads M. Tracking and tracing the tobacco industry: potential tobacco industry influence over the EU's system for tobacco traceability and security features. Tob Control 2020;29:e56-62.

97 Down A, Cheema U. Pakistan's big tobacco problem. Organized Crime and Corruption Reporting Project, 2020. Available: https://www.occrp.org/en/ loosetobacco/without-a-trace/pakistans-big-tobacco-problem [Accessed 09 Apri 2020].

98 Gallagher A, Evans-Reeves K, Joshi A, et al. Analysis of submissions to the EU's public consultation on tobacco traceability and security features. Tob Control 2021:30:e4-9.

99 Stopping Tobacco Organizations \& Products. How the tobacco industry is successfully undermining tobacco tracking and tracing. Case study Pakistan, 2020. Available: https://exposetobacco.org/wp-content/uploads/STOP_TrackandTrace_Pakistan-1.pdf

100 Malone RE, Grundy Q, Bero LA. Tobacco industry denormalisation as a tobacco control intervention: a review. Tob Control 2012;21:162-70.

101 Legg T, Hatchard J, Gilmore AB. The science for profit Model-How and why corporations influence science and the use of science in policy and practice. PLOS One 2021:16:e0253272.

102 White J, Bero LA. Corporate manipulation of research: strategies are similar across five industries. Stan L \& Pol'y Rev 2010:21:105.

103 Daube M. Shining a light on industry research funding. Am J Public Health 2018;108:1441-2.

104 Legg T, Legendre M, Gilmore AB. Paying lip service to publication ethics: scientific publishing practices and the foundation for a smoke-free world. Tob Control 2021:30:e65.

105 Knai C, Petticrew M, Capewell S, et al. The case for developing a cohesive systems approach to research across unhealthy commodity industries. BMJ Glob Health 2021;6:e003543 
106 Stuckler D, McKee M, Ebrahim S, et al. Manufacturing epidemics: the role of global producers in increased consumption of unhealthy commodities including processed foods, alcohol, and tobacco. PLoS Med 2012;9:e1001235.

107 Maani N, Collin J, Friel S, et al. Bringing the commercial determinants of health out of the shadows: a review of how the commercial determinants are represented in conceptual frameworks. Eur J Public Health 2020;30:660-4.

108 McKee M, Stuckler D. Revisiting the corporate and commercial determinants of health. Am J Public Health 2018;108:1167-70.

109 Branston JR. Industry profits continue to drive the tobacco epidemic: a new endgame for tobacco control? Tob Prev Cessat 2021:7:1-3.

110 Hiscock R, Branston JR, Partos TR, et al. Uk tobacco price increases: driven by industry or public health? Tob Control 2019;28:e148-50.

111 World Bank. Taxing tobacco: a win-win for public health outcomes and mobilizing domestic resources, 2018. Available: https://www.worldbank.org/en/topic/tobacco/ brief/taxing-tobacco-a-win-win-for-public-health-outcomes-mobilizing-domesticresources

112 Vermeulen S, Dillen M, Branston J. Big tobacco, big avoidance. The investigative desk, 2020. Available: https://www.bath.ac.uk/publications/big-tobacco-bigavoidance/attachments/Big_Tobacco_Big_Avoidance.pdf

113 Tobacco Tactics. Next generation products, 2020. Available: https://tobaccotactics. org/wiki/next-generation-products

114 Brandt AM. Inventing conflicts of interest: a history of tobacco industry tactics. Am J Public Health 2012;102:63-71.

115 Bero LA. Tobacco industry manipulation of research. late lessons from early warnings: science, precaution, innovation. Copenhagen: European Environment Agency, 2013: 151-78.

116 Brandt A. The cigarette century: the rise, fall and deadly persistence of the product that defined America. New York: Basic Books, 2007

117 Gundle KR, Dingel MJ, Koenig BA. 'To prove this is the industry's best hope': big tobacco's support of research on the genetics of nicotine addiction. Addiction 2010;105:974-83.

118 United States District Court for the District of Columbia. United States v. Philip Morris Civil Action No. 99-CV-02496 (GK): United States' final proposed findings of fact, 2004. Available: https://www.justice.gov/sites/default/files/civil/legacy/2014/09/ 11/U.S.\%20Final\%20PFOF\%20Exec\%20Summary_0.pdf

119 Henningfield JE, Rose CA, Zeller M. Tobacco industry litigation position on addiction: continued dependence on past views. Tob Control 2006;15 Suppl 4:iv27-36.

120 Agaku IT, Adisa AO, Akinyamoju AO, et al. A cross-country comparison of the prevalence of exposure to tobacco advertisements among adolescents aged 13-15 years in 20 low and middle income countries. Tob Induc Dis 2013;11:11.

121 Tobacco Tactics. PMI's IQOS: use, "switching" and "quitting", 2021. Available: https://tobaccotactics.org/wiki/iqos-use/

122 Philip Morris International. Pmi explores global public health issues in new white paperr, 2019. Available: https://www.pmi.com/media-center/press-releases/pressrelease-details/?newsld $=15496$

123 Philip Morris International. "In support of the primacy of science": PMI releases its white paper calling for a future based on scientific evidence, 2020. Available: https:// www.pmi.com/media-center/news/in-support-of-the-primacy-of-science

124 Philip Morris International. Glossary section: harm reduction equation, 2021. Available: https://www.pmi.com/glossary-section/glossary/harm-reductionequation

125 Philip Morris International. Philip Morris gives new year's resolution: "We're trying to give up cigarettes", 2018. Available: https://www.pmi.com/markets/united-kingdom/ en/news/detail/philip-morris-gives-new-year's-resolution-we're-trying-to-give-upcigarettes

126 Philip Morris International. Inventing better alternatives for the greatest number of smokers, 2021. Available: https://www.pmi.com/markets/united-kingdom/en/scienceand-innovation/inventing-better-alternatives

127 Evans-Reeves KA, Hiscock R, Lauber K, et al. Prospective longitudinal study of tobacco company adaptation to standardised packaging in the UK: identifying circumventions and closing loopholes. BMJ Open 2019;9:e028506.

128 Fundación InterAmericana del Corazón. Evidence of PMI marketing of combustible cigarettes in Argentina. personal communication, 2019.

129 Dorado DAJ. Monitoring report Philip Morris international. promotional activities in Colombia, past 12 months. Corporate Accountability International, 2019.

130 Tobacco Tactics. Be Marlboro: Targeting the World's Biggest Brand at Youth, 2020. Available: https://tobaccotactics.org/wiki/be-marlboro-targeting-the-worlds-biggestbrand-at-youth

131 Campaign for Tobacco Free Kids. Philip Morris BOLD: marketing images, 2019. Available: https://www.tobaccofreekids.org/media/2019/2019_04_10_pmbold

132 Evans-Reeves K, Lauber K, Hiscock R. The 'filter fraud' persists: the tobacco industry is still using filters to suggest lower health risks while destroying the environment. Tob Control 2021:tobaccocontrol-2020-056245.

133 Philip Morris International. Our smoke-free products: iqos, 2021. Available: https:// www.pmi.com/smoke-free-products [Accessed 12 Dec 2021].

134 Philip Morris International. 10 facts about the FDA's modified risk tobacco product authorization of iqos, 2020. Available: https://www.pmi.com/our-science/FDAmodified-risk-tobacco-product-authorization-of-IQOS-10-facts
135 United States Food and Drug Administration. FDA authorizes marketing of iqos tobacco heating system with 'reduced exposure' information, 2020. Available: https://www.fda.gov/news-events/press-announcements/fda-authorizes-marketingiqos-tobacco-heating-system-reduced-exposure-information

136 Tobacco Tactics. Pmi promotion of iqos using FDA mrtp order, 2021. Available: https://tobaccotactics.org/wiki/pmi-iqos-fda-mrtp-order/

137 Calantzopoulos A. André Calantzopoulos speech - Boston college chief executives club. Philip Morris International, 2019. Available: https://www.pmi.com/resources/ docs/default-source/newsroom/gallery-other-documents-2/andr\%C3\%A9calantzopoulos-boston-ceo-club-speech-03-05-2019.pdf?sfvrsn=700a91b5_2

138 Kirkham C. Exclusive: Philip Morris suspends social media campaign after Reuters exposes young 'influencers'. Reuters 2019.

139 Dibert C. 10 tips to master influencer marketing on instagram, 2019. Available: https://www.topdrawer.co.uk/Blog/10-tips-to-master-influencer-marketing-oninstagram\#/

140 Campaign for tobacco free kids. IQOS social media examples, 2019. Available: https://www.tobaccofreekids.org/media/2019/iqos-marketing

141 Thrasher JF, Islam F, Barnoya J, et al. Market share for flavour capsule cigarettes is quickly growing, especially in Latin America. Tob Control 2017;26:468-70.

142 Czoli CD, White CM, Reid JL, et al. Awareness and interest in IQOS heated tobacco products among youth in Canada, England and the USA. Tob Control 2020;29:89.

143 Sutanto E, Miller C, Smith DM, et al. Prevalence, use behaviors, and preferences among users of heated tobacco products: findings from the 2018 ITC Japan survey. Int J Environ Res Public Health 2019;16. doi:10.3390/ijerph16234630. [Epub ahead of print: 2111 2019].

144 Kang H, Cho S-I, S-i C. Heated tobacco product use among Korean adolescents. Tob Control 2020:29:466.

145 Hwang JH, Ryu DH, Park S-W. Heated tobacco products: cigarette complements, not substitutes. Drug Alcohol Depend 2019;204:107576.

146 European Commission. European Commission and Philip Morris international sign 12-year agreement to combat contraband and counterfeit cigarettes, 2004. Available: https://ec.europa.eu/commission/presscorner/detail/en/IP_04_882

147 European Commision. European Commission and British American tobacco sign agreement to combat illicit trade in tobacco, 2010. Available: https://ec.europa.eu/ commission/presscorner/detail/en/IP_10_951

148 European Commision. JT International S.A. JT International Holding BV and the European Community and the Participating Member States - Cooperation Agreement, 2007. Available: https://ec.europa.eu/anti-fraud/system/files/2021-07/ cooperation_agreement.pdf

149 European Commision. Co-Operation agreement dated as of 27 September 2010 among imperial tobacco limited and the European Union represented by the European Commission and each member state listed on the signature Pages hereto, 2010. Available: https://ec.europa.eu/anti-fraud/system/files/2021-07/agreement_ sept_2010.pdf

150 Joossens L, Gilmore AB, Stoklosa M, et al. Assessment of the European Union's illicit trade agreements with the four major transnational tobacco companies. Tob Control 2016:25:254.

151 KPMG. Project StAR 2011 results, 2012. Available: https://www.pmi.com/resources/ docs/default-source/pmi-sustainability/star-report-2011.pdf?sfvrsn=3f02b0b5 0

152 Tobacco Tactics. KPMG, 2017. Available: https://tobaccotactics.org/wiki/kpmg/

153 Gilmore AB, Rowell A, Gallus S, et al. Towards a greater understanding of the illicit tobacco trade in Europe: a review of the PMI funded 'Project Star' report. Tob Control 2014;23:e51-61.

154 Tobacco Tactics. Digital Coding \& Tracking Association (DCTA), 2020. Available: https://tobaccotactics.org/wiki/digital-coding-tracking-association-dcta/

155 Philip Morris International. Philip Morris international provides 15 million Euro contribution to INTERPOL to fight trafficking in illicit goods, 2012. Available: https:// web.archive.org/web/20161112140956/http://www.pmi.com/eng/media_center/ press_releases/pages/201206210200.aspx

156 Tobacco Tactics. Interpol, 2018. Available: https://tobaccotactics.org/wiki/interpol/

157 Tobacco Tactics. Oxford economics, 2020. Available: https://tobaccotactics.org/wiki/ oxford-economics

158 International Tax and Investment Center, Oxford Economics. Asia-11 illicit tobacco indicator 2012, 2013. Available: https://www.oxfordeconomics.com/recent-releases/ asia-11-illicit-tobacco-indicator-2012

159 KPMG G. Track and trace approaches in tobacco. Available: https://www.gs1uk.org/ sites/default/files/GS1_UK_and_KPMG_Track_and_Trace_in_Tobacco_May_2014. pdf

160 Digital Coding and Tracking Association. Dcta technology ownership transferred to Inexto. an affiliate of Impala Group 2016 https://content.tobaccotactics.org/uploads/ 2020/02/DCTA_Press-Release_1June2016.pdf

161 Tobacco Tactics. Pmi impact, 2017. Available: https://tobaccotactics.org/wiki/pmiimpact/

162 Tobacco Tactics. Transnational alliance to combat illicit trade (TRACIT), 2021. Available: https://tobaccotactics.org/wiki/tracit/\#: :text=The\%20Transnational\% 20Alliance $\% 20$ to\%20Combat, \%2Dfoods\%2C\%20petroleum $\% 20$ and $\%$ 20pharmaceuticals 
163 HM Government of Gibraltar. Gibraltar and JTI take a step forward against the illegal trade of tobacco products - 86/2020, 2020. Available: https://web.archive.org/web/ 20211115100639/https://www.gibraltar.gov.gi/press-releases/gibraltar-and-jti-takea-step-forward-against-the-illegal-trade-of-tobacco-products-862020-5591

164 Crosbie E, Bialous S, Glantz SA. Memoranda of understanding: a tobacco industry strategy to undermine illicit tobacco trade policies. Tob Control 2019;28:e110-8.

165 Oxford Economics. Levant illicit tobacco 2019, 2020. Available: https://www. oxfordeconomics.com/recent-releases/levant-illicit-tobacco-2019

166 Philip Morris International. Fighting illicit tobacco trade, 2020. Available: https:// www.stopillegal.com/docs/default-source/position-papers/fighting-illicit-tobaccotrade-pmi-position-paper-june-2020.pdf

167 Philip Morris International. Combatting illicit whites, 2019. Available: https://www. pmi.com/sustainability/fighting-illicit-tobacco-trade/combatting-illicit-whites
168 Japan Tobacco International. What we're foing to fight the illegal trade, 2021. Available: https://www.jti.com/news-views/what-were-doing-to-fight-illegal-trade

169 World Bank. Confronting illicit tobacco trade: a global review of country experiences: technical report of the world bank group global tobacco control program, 2019. Available: https://documents1.worldbank.org/curated/en/677451548260528135/ pdf/133959-REPL-PUBLIC-6-2-2019-19-59-24-WBGTobaccolllicitTradeFINALvweb. pdf

170 Filippidis FT, Chang KKC, Blackmore I, et al. Prices and illicit trade of cigarettes in the European Union: a cross-sectional analysis. Nicotine Tob Res 2020;22:2271-5

171 British American Tobacco. Fighting the black market: a United response to a global problem, 2021. Available: https://www.bat.com/group/sites/uk_9d9kcy.nsf/ vwPagesWebLive/D0933J8E\# [Accessed 14 Dec 2021] 